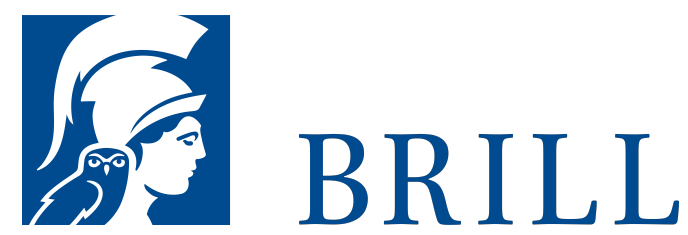

\title{
Tod ohne Leitbild?
}

Philosophische Untersuchungen zu einem integrativen

Todeskonzept

Author: Daniel Kersting

Tod und Sterben waren schon immer von leitenden

Vorstellungen geprägt: Die Topoi des sanften Todes, des bewussten Abschieds, des friedlichen Einschlafens haben eine lange Tradition. Auch unsere gegenwärtige Gesellschaft entwirft solche Leitbilder und propagiert etwa den Heldentod als Organspenderin, verspricht das ruhige und friedliche Sterben im Hospiz oder bestimmt den »Hirntod « zum Tod des Menschen. In der konkreten Umsetzung führen diese Vorstellungen allerdings oft zu Konflikten, die von den Beteiligten selbst nicht mehr gelöst werden können. Die Studie verfolgt die Hypothese, dass diese Konflikte in einem vereinseitigten Verständnis des Todes gründen, das insbesondere die personale Bedeutung des Todes nicht angemessen berücksichtigt. In einer kritischen Auseinandersetzung mit aktuellen philosophischen Theorien es Todes wird das Problem zunächst begrifflich präzisiert, um es dann mit den Mitteln der philosophischen Anthropologie Helmuth Plessners zu lösen. Dabei wird ein Konzept des menschlichen Todes entwickelt, das die personale Bedeutung ebenso wie andere zentrale Dimensionen des Todes integriert. Dieser integrative Ansatz ermöglicht, Todesvorstellungen kritisch auf ihre Legitimität zu prüfen.

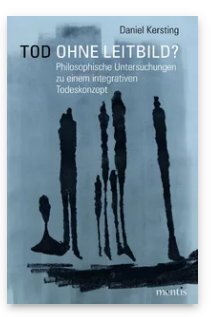

Pages: 336

Seiten

Language:

German

Subjects:

General,

Philosophy

Publisher: Brill | mentis

E-Book (PDF)

Released online:

o1 Oct 2017

ISBN: 978-3-

95743-826-3

List price

Paperback

Publication date:

o1 Oct 2017

ISBN: 978-3-

95743-094-6

List price 
For more information see brill.com

Order information: Order online at brill.com +44330 333 0049 | customerservices@brill.com Submission information: brill.com/authors

Titles published by Brill | Fink, Brill | mentis or Brill | Schöningh: +49(o)715413279216| brill@brocom.de 